\title{
Integrated Remote Sensing and GIS Analysis for Landslide Susceptibility Assessment along the Trenggalek-Ponorogo Road, East Java Province, Indonesia
}

\author{
Adniwan Shubhi Banuzaki*, Adelia Kusuma Ayu \\ Balai Besar Pelaksanaan Jalan Nasional Jawa Timur-Bali \\ Ministry of Public Works and Housing, \\ Waru Main St. No. 20, Sidoarjo, Jawa Timur, 61256, Indonesia \\ *E-mail: adniwan.banuzaki@pu.go.id
}

Article received: 5 February 2021, revised: 26 February 2021, accepted: 9 March 2021

DOI: $10.51835 /$ iagij.2021.1.1.14

\begin{abstract}
Landslide, the second most common hazard in Indonesia, after an earthquake, is causing enormous losses of public infrastructures with subsequent economic disruptions. Roads are the most frequent public property which is affected by landslides. Due to the geomorphological condition of Indonesia, the construction of roads often intersects the mountainous topography. The Trenggalek-Ponorogo Road is one of the roads passing through mountainous terrains that are very susceptible affected by landslides. The road has an important role as the main transportation connector of some regencies in East Java Province. Landslide mitigation strategies along the Trenggalek-Ponorogo Road are needed to prevent enormous losses. This research was aimed to conduct a remote sensing-based assessment of landslide susceptibility areas along the Trenggalek-Ponorogo Road. The landslide susceptibility areas were assessed by considering landslide triggering parameters; those were topographic slope, distance to geological structure, distance to stream, lithology, and land use/land cover. The landslide triggering parameters were presented in spatial data and processed using Geographic Information System (GIS) technology. The Analytical Hierarchy Process (AHP) method was applied to integrate the landslide triggering parameters which have the degree of effect to determine Landslide Potential Index (LPI). The resulting LPI delineated the area into four susceptibility zones: very high, high, moderate, and low, which were presented as landslide susceptibility map. The susceptibility map was then validated by landslide occurrences inventory in the study area. The very high susceptibility zones, which are strongly predicted affecting the Trenggalek-Ponorogo Road, are located in Nglinggis and Grogol Village.
\end{abstract}

Keywords: Trenggalek, Ponorogo, remote sensing, GIS, landslide

\section{INTRODUCTION}

Landslide is defined as a downslope movement of rock or soil, or both, occurring on the surface of rupture [1]. In natural condition, landslides frequently occurred in mountainous areas with a high rate of weathering. Human activities, or urbanization processes, often enhance the probability of landslide due to uncontrolled urbanization development. In Indonesia, landslides are frequently occurred hazard causing manifold socio-economic implications in terms of both direct and indirect costs [2]. The road infrastructures are the most common affected infrastructure causing disturbed logistic distributions and closed accessibility of roads that lead to economic deprivation. Landslide susceptibility assessment along the road infrastructures in wide mountainous areas is not easy to be conducted due to the limited human resources. 
The Trenggalek-Ponorogo Road experienced landslide due to lack of susceptibility monitoring as evidenced by several landslide occurrences. Landslides in the Trenggalek - Ponorogo Road has causing close access between two regencies (Trenggalek and Ponorogo Regency) [3]. Landslide management is needed in the road since it plays an important role to support many activities between two (or more) regencies.

This research was aimed to assess the landslide-prone slopes and produce the landslide susceptibility map along Trenggalek-Ponorogo Road that will help the government to arrange the slope management strategies. The research was conducted using the integration of GIS technology with remote sensing data. The Analytical Hierarchy Process and simple rating method were incorporated to produce Landslide Potential Index (LPI). In Indonesia, the application of remote sensing and GIS technology was rarely implemented for landslide susceptibility assessment. Meanwhile, in other countries, the integration of remote sensing and GIS technology had widely used in landslide susceptibility assessment due to many good reasons, such as saving time and resources as well as the precise result [4]. The method was very suitable conducted in the wide research area without spending a lot of time and money.

The research was conducted along the Trenggalek-Ponorogo Road and the surrounding area. The total research area is $190 \mathrm{~km}^{2}$ and the total length of road is 27.68 $\mathrm{km}$ (Figure 1). The road connects Trenggalek and Ponorogo Regency in East Java Province, Indonesia. The road was constructed passing through adverse geomorphological and geological conditions. Most parts of the road were constructed in mountainous terrain by cutting the original slopes of mountainous terrain. Whereas, the types of lithology composing the mountainous terrain are dominated by weathered tertiary volcanic rocks with quite intensive structural geology $[5,6]$. The implications of both conditions are the high number of landslide-susceptibility areas (Table 1).

Table 1. Landslide inventory in study area [3,7-9].

\begin{tabular}{ccl}
\hline Code & $\begin{array}{c}\text { UTM } \\
\text { Coordinate } \\
\text { (49S Zone) }\end{array}$ & \multicolumn{1}{c}{ Failure Mechanism } \\
\hline 1 & 563411,9116758 & Subsidence \\
2 & 565943,9111570 & Debris slide \\
3 & 568860,9119627 & Slump, crack, soil creep \\
4 & 568319,9117997 & Slump, crack, soil creep \\
5 & 568625,9118098 & Debris slide \\
6 & 570031,9120433 & Slump, irregular crack \\
7 & 571161,9118699 & Slump, crack \\
8 & 572227,9119057 & Slump, crack \\
9 & 571847,9115231 & Slump, crack \\
10 & 570643,9116220 & Crack, soil creep \\
\hline
\end{tabular}

Source: Geological Agency of Indonesia and National Agency for Disaster Management.

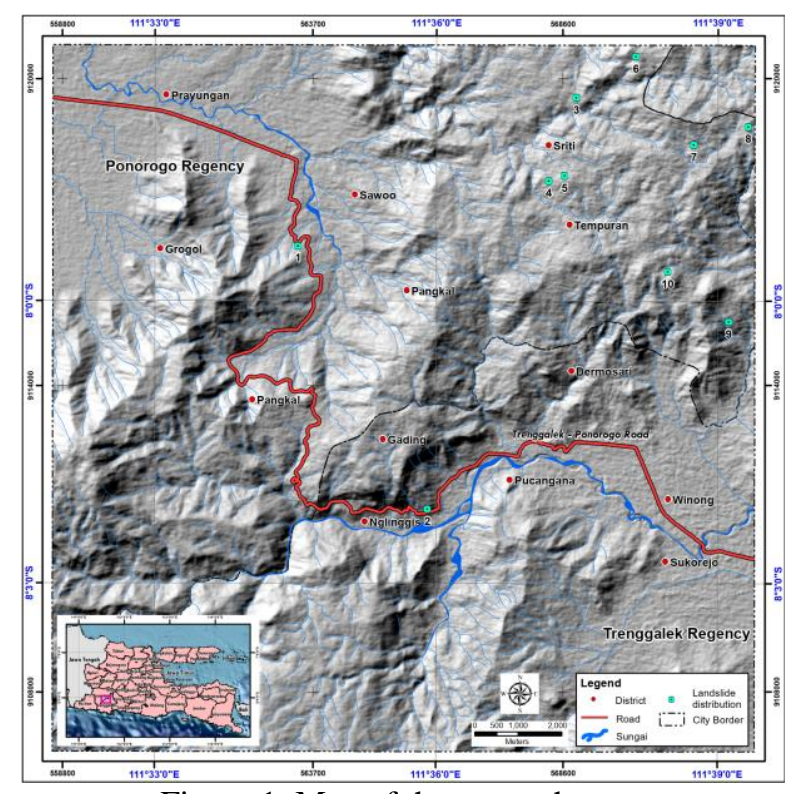

Figure 1. Map of the research area.

\section{DATA AND METHODS}

Landslide is the result of the interaction of many triggering parameters. The knowledge that says landslide is only 
associated with extremely steep slopes does not accurately reflect the real condition of the research area. The assessment of landslide susceptibility has to consider the various adverse triggering parameters. The establishment of landslide triggering parameters in this research was supported by the landslide inventory data. There are five triggering parameters associated with the landslide distributions of the research area, those are topographic slope, lithology, distance to lineament/geological structure, distance to stream, and land use. The landslide triggering parameters in this research represented both the natural (geological and hydrological aspect) and anthropogenic controls.

The information of the triggering parameters in the research area was extracted from remote sensing data and published map (Table 2) and then presented in a raster-based thematic map of parameters. The detailed conditions of the parameters are described as follows.

Table 2. The data sources of landslide parameters $[5,6,10,11]$.

\begin{tabular}{|c|c|c|}
\hline $\begin{array}{l}\text { Thematic } \\
\text { data maps }\end{array}$ & Data source & $\begin{array}{l}\text { Original } \\
\text { scale/resolution }\end{array}$ \\
\hline $\begin{array}{l}\text { Slope } \\
\text { angle }\end{array}$ & $\begin{array}{l}\text { Digital Elevation } \\
\text { Model (DEM) } 1507- \\
44,1507-53,1508- \\
12,1508-21 \text { from } \\
\text { Indonesia Geospatial } \\
\text { Information Agency }\end{array}$ & 0.27 -arcsecond \\
\hline $\begin{array}{l}\text { Lithology } \\
\text { and } \\
\text { distance to } \\
\text { lineament/ } \\
\text { geological } \\
\text { structure }\end{array}$ & $\begin{array}{l}\text { Geological map of } \\
\text { the Madiun and } \\
\text { geological map of } \\
\text { the Tulungagung } \\
\text { from Geological } \\
\text { Research and } \\
\text { Development Centre }\end{array}$ & $1: 100,000$ \\
\hline $\begin{array}{l}\text { Land use } \\
\text { and } \\
\text { Distance to } \\
\text { stream }\end{array}$ & $\begin{array}{l}\text { Topographical map } \\
\text { of Ponorogo and } \\
\text { Trenggalek from } \\
\text { Indonesia Geospatial } \\
\text { Information Agency }\end{array}$ & $1: 25,000$ \\
\hline
\end{tabular}

- Slope Angle

Slope angle is an important landslide causative factor. It controls the shear forces acting on the hill slopes [12]. The steep slope, usually, has greater shear forces than shear strength which makes the soil/rock mass moving. The study of landslide susceptibility, so far, always considers the slope angle [13-19]. In this research, the slope angle data were derived from remote sensing data provided by the government in the form of the Digital Elevation Model (DEM). The slope angles in the research area, which ranged in vary value, were classified into five classes: (i) $>25^{\circ}$; (ii) $15-25^{\circ}$; (iii) $10-15^{\circ}$; (iv) $5-10^{\circ}$; (v) $0-5^{\circ}$ (Figure 2a).

- Lithology

Lithology has a strong correlation with the distribution of landslides in the research area. Lithology plays an important role to determine the weathering resistance of a slope/escarpment [20]. The lithology data in the research area was gained from geological maps of Ponorogo and Tulungagung published by the Geological Research and Development Centre. The rock formations with similar characteristic were regrouped into a bigger class of rock. There were five classes of rocks in the research area (Figure 2b), those were quaternary deposit, limestone, volcanic breccia, sandstone and diorite [5,6].

- Distance to Lineament/Geological Structure

Lineament is the surface manifestation of geological structures. It indicates the presence of geological structures beneath the earth surface. In the research area, 
geological structures intensively intersect the hills. Geological structures provide discontinuities in rock bodies which can enhance the weathering process. The distance of slope to the geological structure has a direct relationship to landslide occurrences. The closer the distance of the slope to the geological structure, the more intensive the discontinuities [21]. The geological structures data in the research area was gained from geological maps of Ponorogo and Tulungagung published by the Geological Research and Development Centre. The research area was divided into five zones based on the distance to geological structures, those were: (i) 0-200 m; (ii) 200-400 m; (iii) 400-700 m; (iv) 700-1,000 m; (v) $>1,000 \mathrm{~m}$ (Figure 2c).

- Distance to Stream

The research area has a very intensive stream pattern. Most streams are formed by surface runoff from rainfall water. Considering this phenomenon, the streams become responsible for determining the water content in the surrounding soils/rocks. The distances of slope to streams become an important factor of slope instability. Different researchers had used the distance to stream as one of consideration in landslide susceptibility assessment $[14,15,19,20]$. It becomes the representation of the hydrological aspect in landslide susceptibility assessment. The research area was divided into five zones based on the distance to streams, those were: (i) $0-50 \mathrm{~m}$; (ii) $50-100 \mathrm{~m}$; (iii) $100-150 \mathrm{~m}$; (iv) $150-200 \mathrm{~m}$; (v) $>200 \mathrm{~m}$ (Figure 2d).

- Land Use

Land use represents the anthropological activities that contribute to surface/morphological change. It plays an important role in slope instability [22]. The land use data in the research area was gained from a topographical map published by Indonesia Geospatial Information Agency. The research area was divided into five land-use types, those were: water body, built-up area, barren land, agricultural land, and forest (Figure 2e).

Landslide susceptibility map was generated by integrating five thematic maps (Figure 3). The integration of all thematic maps was conducted in two stages of processes; those were AHP and a simple rating method. Different researchers, who had used AHP for landslide susceptibility assessment, noted some advantages of the AHP method are: (i) all information can be included in the assessment process; (ii) judgement is structured; (iii) discussion rules are based on expert's knowledge and experiences; (iv) inconsistencies in the decision process can be detected [23]. In this research, AHP was used only to assign the rank of landslide triggering parameters but not for the different classes of the parameters. The assignment of the parameters' classes was conducted using a simple rating. Every step of the methodology is explained as follows. 


\section{IAGI Journal}

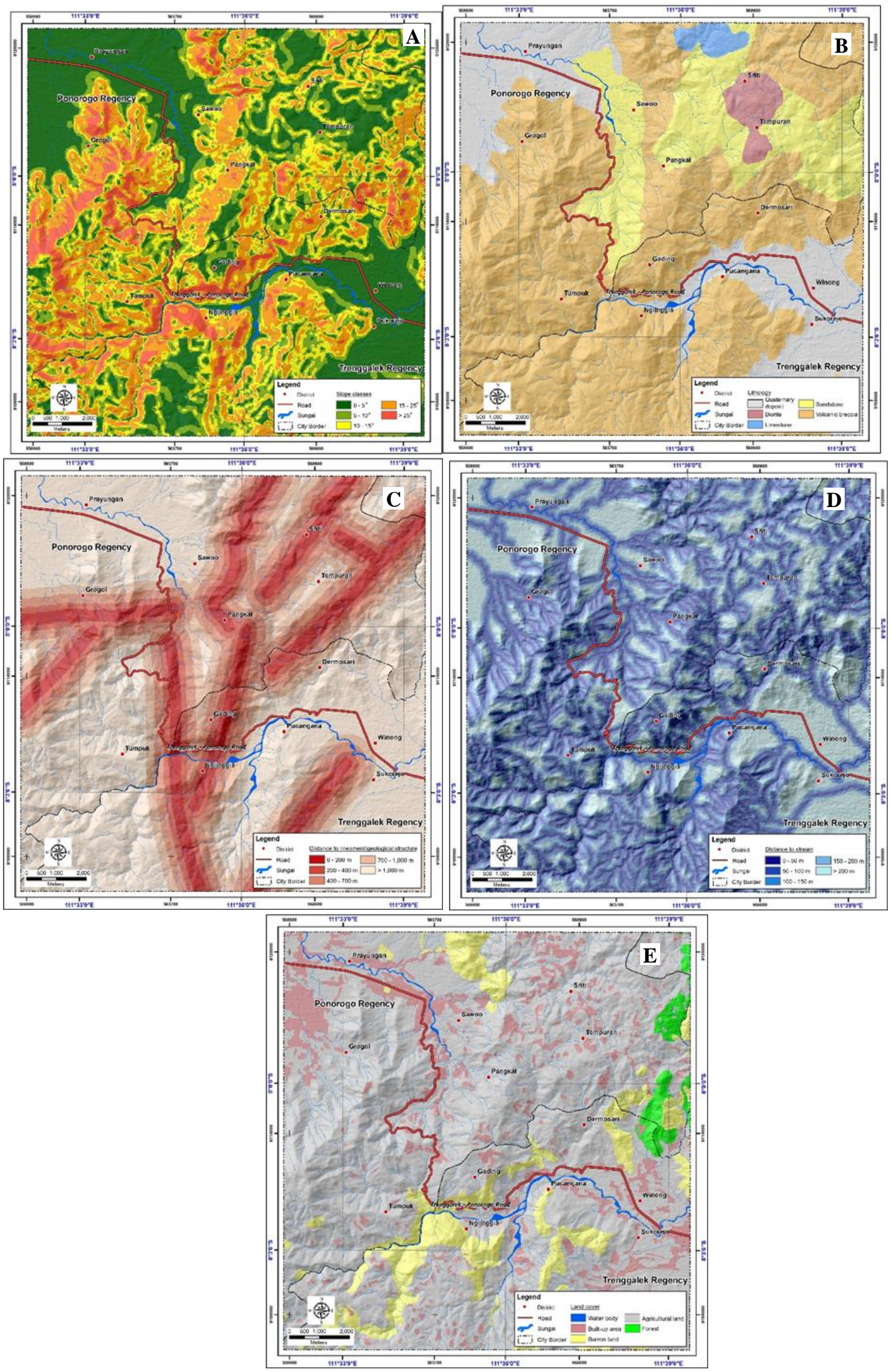

Figure 2. Thematic maps of landslide triggering parameters: (A) slope angle map; (B) lithology map; (C) distance to lineament/geological structure map; (D) distance to stream map; (E) land use map. 


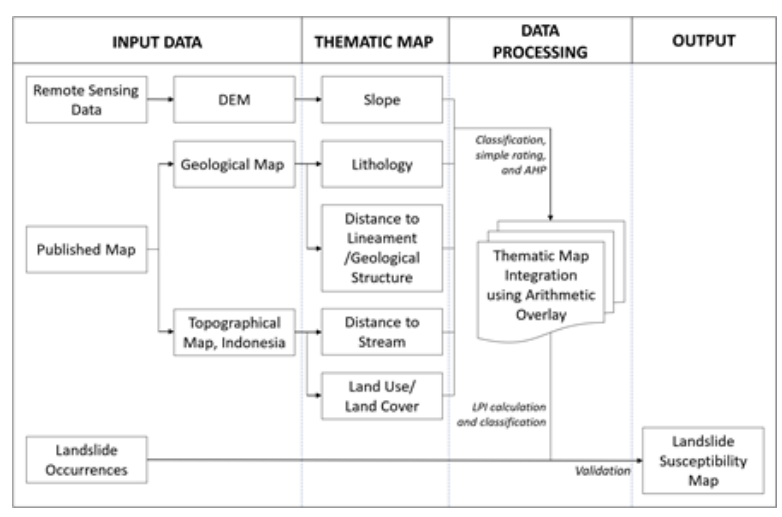

Figure 3. Research methodology.

The first step was determining the rank of each parameter. The AHP method was applied in the assignment. The assignments are taken using pairwise relative comparisons of the parameters without inconsistencies incorporated in the assignment process [24]. The inconsistency can be checked using a consistency ratio $(\mathrm{CR})$. If the $\mathrm{CR}>0.1$, the comparison matrix is inconsistent and should be revised. The final result of pairwise comparison is the ranking of triggering parameters in this research can be seen in Table 3. From this assignment, we got the rank of parameters that represented the degree of importance of the parameters to trigger a landslide. The slope angle parameter took the first position and the land use was at the last position.

Table 3. Pairwise comparison matrix.

\begin{tabular}{|c|c|c|c|c|c|c|c|}
\hline \multicolumn{2}{|c|}{$\begin{array}{c}\text { Landslide } \\
\text { triggering } \\
\text { parameters }\end{array}$} & (1) & (2) & (3) & (4) & (5) & $\begin{array}{l}\text { Final } \\
\text { Rank }\end{array}$ \\
\hline Slope angle & (1) & 1 & 2 & 3 & 5 & 7 & $42.5 \%$ \\
\hline Lithology & (2) & $1 / 2$ & 1 & 2 & 4 & 6 & $27.3 \%$ \\
\hline $\begin{array}{l}\text { Distance to } \\
\text { geological } \\
\text { structure/ } \\
\text { lineament }\end{array}$ & (3) & $1 / 3$ & $1 / 2$ & 1 & 3 & 5 & $17.7 \%$ \\
\hline $\begin{array}{l}\text { Distance to } \\
\text { stream }\end{array}$ & (4) & $1 / 5$ & $1 / 4$ & $1 / 3$ & 1 & 3 & $8.4 \%$ \\
\hline Land use & (5) & $1 / 7$ & $1 / 6$ & $1 / 5$ & $1 / 3$ & 1 & $4.2 \%$ \\
\hline
\end{tabular}

The second step was determining the weight of classes in each parameter. The value of weighting ranged between $0-9$ which represented the degree of influence to trigger a landslide. The higher value has a bigger influence to trigger a landslide. Implementation of a simple rating method in this research aimed to give a chance to the researcher for assigning the degree of importance as real as the natural condition of the research area. The assignment of classes using a simple rating method can be seen in Table 4.

Table 4. The assignment of landslide triggering parameters classes

\begin{tabular}{lll}
\hline Causative factors & Classes & Weight \\
(1) & (2) & (3) \\
\hline Slope angle & $>25^{\circ}$ & 9 \\
& $15-25^{\circ}$ & 8 \\
& $10-15^{\circ}$ & 5 \\
& $5-10^{\circ}$ & 2 \\
Lithology & $0-5^{\circ}$ & 1 \\
& Quaternary deposit & 9 \\
& Limestone & 8 \\
Volcanic breccia & 7 \\
Distance to & Sandstone & 3 \\
structure/lineament & Diorite & 2 \\
& $0-200 \mathrm{~m}$ & 9 \\
& $200-400 \mathrm{~m}$ & 7 \\
Distance to stream & $400-700 \mathrm{~m}$ & 4 \\
& $700-1,000 \mathrm{~m}$ & 2 \\
& $>1,000 \mathrm{~m}$ & 1 \\
& $0-50 \mathrm{~m}$ & 9 \\
& $50-100 \mathrm{~m}$ & 7 \\
& $100-150 \mathrm{~m}$ & 4 \\
Land use & $150-200 \mathrm{~m}$ & 2 \\
& $>200 \mathrm{~m}$ & 1 \\
& Water body & 9 \\
& Built-up area & 8 \\
& Barren land & 4 \\
& Agricultural land & 3 \\
& Forest & 1 \\
\hline & &
\end{tabular}

The third step was integrating data. The integration was a process of an arithmetic overlay to combine all of the thematic maps which had numerical data layers of landslide triggering parameters and their classes (Table 5). The map overlay was conducted in GIS software using the tool "Weighted Overlay" following the formula of Landslide Potential 
Index (LPI) that had been demonstrated [21] as follows.

$$
L P I=\sum_{i=1}^{5}\left(R_{i} x W_{i j}\right)
$$

where $\mathrm{R}_{\mathrm{i}}$ denotes the rank for factor $\mathrm{i}$ and $\mathrm{W}_{\mathrm{ij}}$ denote the weight of class $j$ of factor $i$.

The LPI, gained from overlay process, was classified into four classes which delineated the research area into four classes of landslide susceptibility (Table 6) and presented as a landslide susceptibility map of the research area. The resulting map was, then, validated using landslide inventory data as stated in Table 1 . The validation showed a relatively precise result, where the very high susceptibility zone has higher landslide occurrences than the other zones (Figure 4). sufficient to validate the zonation. The collected data of landslide inventory was very difficult due to the limited information provided by the government. After validated, the landslide susceptibility map along the Trenggalek-Ponorogo Road was ready to be used (Figure 5).

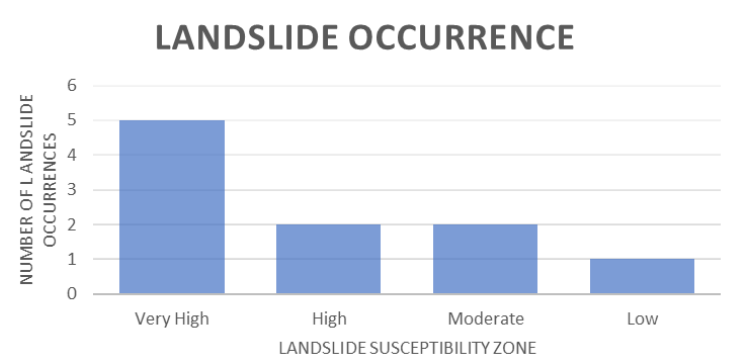

Figure 4. Distribution of landslide occurrences in the landslide susceptibility zones.

However, the number of landslide occurrences in inventory data was not

Table 5. Integration of landslide triggering parameters and their classes.

\begin{tabular}{|c|c|c|c|c|}
\hline $\begin{array}{c}\text { Causative } \\
\text { factors } \\
(1)\end{array}$ & $\begin{array}{c}\text { Classes } \\
\text { (2) }\end{array}$ & $\begin{array}{c}\text { Rank of } \\
\text { parameters } \\
(3)\end{array}$ & $\begin{array}{l}\text { Weight of } \\
\text { classes } \\
(4)\end{array}$ & $\begin{array}{l}\text { Final weight } \\
(5)=(3) \times(4)\end{array}$ \\
\hline Slope & $>25^{\circ}$ & $42.5 \%$ & 9 & 3.825 \\
\hline \multirow[t]{4}{*}{ angle } & $15-25^{\circ}$ & & 8 & 3.400 \\
\hline & $10-15^{\circ}$ & & 5 & 2.125 \\
\hline & $5-10^{\circ}$ & & 2 & 0.850 \\
\hline & $0-5^{\circ}$ & & 1 & 0.425 \\
\hline \multirow[t]{5}{*}{ Lithology } & Quaternary deposit & $27.3 \%$ & 9 & 2.457 \\
\hline & Limestone & & 8 & 2.184 \\
\hline & Volcanic breccia & & 7 & 1.911 \\
\hline & Sandstone & & 3 & 0.819 \\
\hline & Diorite & & 2 & 0.546 \\
\hline Distance to & 0-200 m & $17.7 \%$ & 9 & 1.593 \\
\hline geological & $200-400 \mathrm{~m}$ & & 7 & 1.239 \\
\hline structure/ & $400-700 \mathrm{~m}$ & & 4 & 0.708 \\
\hline \multirow[t]{2}{*}{ lineament } & $700-1,000 \mathrm{~m}$ & & 2 & 0.354 \\
\hline & $>1,000 \mathrm{~m}$ & & 1 & 0.177 \\
\hline \multirow{5}{*}{$\begin{array}{l}\text { Distance to } \\
\text { stream }\end{array}$} & $0-50 \mathrm{~m}$ & $8.4 \%$ & 9 & 0.756 \\
\hline & $50-100 \mathrm{~m}$ & & 7 & 0.588 \\
\hline & $100-150 \mathrm{~m}$ & & 4 & 0.336 \\
\hline & $150-200 \mathrm{~m}$ & & 2 & 0.168 \\
\hline & $>200 \mathrm{~m}$ & & 1 & 0.084 \\
\hline \multirow[t]{5}{*}{ Land use } & Water body & $4.2 \%$ & 9 & 0.378 \\
\hline & Built-up area & & 8 & 0.336 \\
\hline & Barren land & & 4 & 0.168 \\
\hline & Agricultural land & & 3 & 0.126 \\
\hline & Forest & & 1 & 0.042 \\
\hline
\end{tabular}


Table 6. Classification of LPI.

\begin{tabular}{ll}
\hline Landslide susceptibility class & LPI \\
\hline Low & $1-4$ \\
Moderate & $4-5$ \\
High & $5-6$ \\
Very High & $6-9$ \\
\hline
\end{tabular}

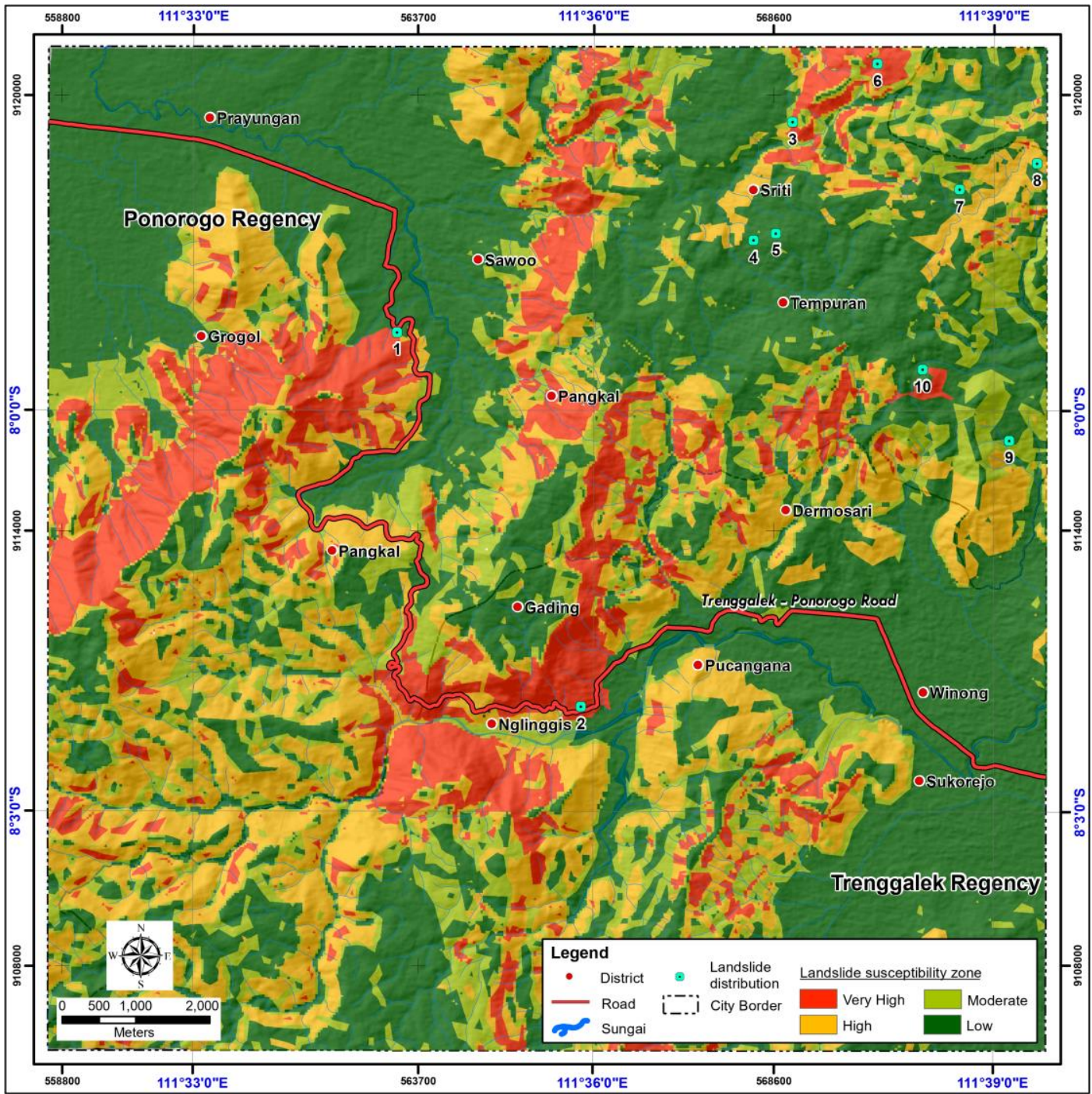

Figure 5. Landslide susceptibility map in the research area.

\section{RESULTS AND DISCUSSION}

Based on the landslide susceptibility map that had been produced, the TrenggalekPonorogo Road passes through mostly in a low susceptibility map. However, there are some parts of the road that need to be considered:

- In Nglinggis Village, Trenggalek Regency, approximately 5 kilometers of road is located in a very high susceptibility zone.

- In Pangkal Village, Ponorogo Regency, approximately 3 kilometers of road is located in high susceptibility zone.

- In Grogol Village, Ponorogo Regency, approximately 0.6 kilometers of road is located in a very high susceptibility zone 
and about 1.5 kilometers of road is located in high susceptibility zone.

The road in Nglinggis $(5 \mathrm{~km})$ and Grogol $(0.6 \mathrm{~km})$ Village has the highest probability of landslide because it is located alongside the river, steep mountainous slope with relatively low vegetation, composed of highly weathered volcanic breccia and also occupied by a normal fault. Meanwhile, the road in Pangkal $(3 \mathrm{~km})$ and Grogol $(1.5 \mathrm{~km})$ Village are located on a steep mountainous slope with agricultural vegetation, composed of highly weathered volcanic breccia and relatively near to normal fault.

The protocol of landslide mitigation strategies is needed in both of the locations. The strategies must fit the nature condition of slopes, including geotechnical and hydrological aspects, so they can be implemented properly to prevent landslides. Furthermore, the implementation of the early warning system is also needed to monitor the relevance of landslide parameters.

\section{CONCLUSIONS}

The landslide susceptibility assessment along Trenggalek-Ponorogo Road using integrated remote sensing data and GIS technology had evidenced the reliable landslide susceptibility map. There are three locations of the road which need to be considered, those are in Nglinggis, Pangkal, and Grogol Village which have very high landslide susceptibility and high landslide susceptibility. The researchers suggest that the onsite investigation must be conducted immediately to arrange mitigation and management strategies.

\section{REFERENCES}

1. Highland, L.M.; Bobrowsky, P. The landslide handbook-A guide to understanding landslides.
In U.S. Geological Survey Circular; 2008.

2. Karnawati, D.; Fathani, T.F.; Andayani, B.; Burton, P.W.; Sudarno, I. Strategic program for landslide disaster risk reduction: a lesson learned from Central Java, Indonesia. WIT Trans. Built Environ. 2009, 110, 115-126.

3. National Agency for Disaster Management No Title Available online: https://bnpb.cloud/dibi/.

4. Yamagishi, H.; Bhandary, N.P. GIS Landslide; Tokyo, 2017;

5. Hartono, U.; Baharuddin; Brata, K. Geological Map of the Madiun Quadrangle, Jawa,; Bandung, 1992;

6. Samodra, H.; Suharsono, S.; Gafoer; Suwarti, T. Geological Map of the Tulungagung Quadrangle, Jawa; 1992;

7. Geological Agency of Indonesia Response for Landslide Disaster in Tugu District, Trenggalek Regency, East Java.; 2016;

8. Geological Agency of Indonesia Report of Lanslide Survey in Sawoo, Pulung, Ngebel, and Slahung, Ponorogo Regency, East Java; 2017;

9. Geological Agency of Indonesia Response for Landslide Disaster in Sawoo and Sokoo District, Trenggalek Regency, East Java; 2017;

10. Indonesia Geospatial Information Peta rupa bumi Available online: https://tanahair.indonesia.go.id/portal-web/ download/perwilayah.

11. Indonesia Geospatial Information Agency DEMNAS 1507-44, 1507-53, 1508-12, 1508-21.

12. Dou, J.; Bui, D.T.; Yunus, A.P.; Jia, K.; Song, X.; Revhaug, I.; Xia, H.; Zhu, Z. Optimization of Causative Factors for Landslide Susceptibility Evaluation Using Remote Sensing and GIS Data in Parts of Niigata, Japan. PLoS One 2015, 10.

13. Clerici, A.; Perego, S.; Tellini, C.; Vescovi, P. A Procedure for Landslide Susceptibility Zonation by the Conditional Analysis Method. Geomorphology 2002, 48, 349-364.

14. Saha, A.K.; Gupta, R.P.; Arora, M.K. GIS-Based Landslide Hazard Zonation in the Bhagirathi (Ganga) Valley, Himalayas. Int. J. Remote Sens. 2002, 23, 357-369.

15. Cevik, E.; Topal, T. GIS-based Landslide Susceptibility Mapping for a Problematic Segment of the Natural Gas Pipeline, Hendek (Turkey). Environ. Geol. 2003, 44, 949-662.

16. Ercanoglu, M.; Gokceoglu, C.; Van Asch, T.W.J. Landslide Susceptibility Zoning North of Yenice (NW Turkey) by Multivariate Statistical Techniques. Nat. Hazards 2004, 32, 1-23.

17. Lee, S.; Choi, J.; Min, K. Probabilistic Landslide Hazard Mapping Using GIS and Remote Sensing Data at Boun, Korea. Korea, Int. J. Remote Sens. 2004, 25, 2037-2052.

18. Lee, S. Application of Logistic Regression Model and Its Validation for Landslide Susceptibility 
Mapping Using GIS and Remote Sensing Data. Int. J. Remote Sens. 2005, 26, 1477-1491.

19. Yalcin, A. GIS-Based Lanslide Susceptibility Mapping Using Analytical Hierarchy Process and Bivariate Statistics in Ardesen (Turkey) Comparisons of Results And Confirmation. Catena 2008, 72, 1-12.

20. Dai, F.C.; Lee, C.F.; Li, J.; Xu, Z.W. Assessment of Landslide Susceptibility on the Natural Terrain of Lantau Island, Hong Kong. Environ. Geol. 2001, 43, 381-391.

21. Sarkar, S.; Kanungo, D.P. An Integrated Approach for Landslide Susceptibility Mapping Using Remote Sensing and GIS. Photogramm.
Eng. Remote Sens. 2004, 70, 616-625.

22. Hamza, T.; Raghuvanshi, T.K. GIS Based Landslide Hazard Evaluation and Zonation - a Case from Jeldu District, Central Ethiopia. $J$. King Saud Univ. - Sci. 2017, 29, 151-65.

23. Kayastha, P.; Dhital, M.R.; De Smedt, F. Application of The Analytical Hierarchy Process (AHP) for Landslide Susceptibility Mapping: a Case Study From the Tinau Watershed, West Nepal. Comput. Geosci. 2012, 52, 398-308.

24. Saaty, T.L. The Analytic Hierarchy Process: Planning, Priority Setting, Resource Allocation; New York, 1980; 